\title{
Development and Optimization of Nutritionally Enhanced Wheat Breads Supplemented with tef (Eragrostistef (Zucc.) Trotter) Grain Flour
}

\author{
Tamrat Kore, Workineh Abebe, Muhaba Seifu, Oli Legese, Deribe Mengistu, Semhal Maresha and \\ LamsgenYegrem \\ Debrezeit Agriculture Research Center, EIAR, Bishoftu, Ethiopia. P.O. Box: 32
}

\begin{abstract}
The aim of this study was to develop nutritionally enhanced and healthy bread through incorporation of tef flour to wheat flour. Accordingly, the influence of tef (brown and white) flour incorporation ( $0-40 \%$ tef flour) on wheattef blend flour physicochemical properties, baking characteristics and bread nutritional and sensorial qualities was evaluated. Incorporation of tef flour significantly increased water absorption capacity (57.67 to 97.00\%), reduced both wet gluten (29.33 to $13.89 \%$ ) and dry gluten (12.03 to $6.37 \%$ ) content of composite flour. All the tef containing bread showed better mineral content $(\mathrm{Ca}, \mathrm{Fe}, \mathrm{Mn}, \mathrm{Zn}, \mathrm{Mg}, \mathrm{K}$ and $\mathrm{Na}$ ), good fiber and fat content as compared to wheat flour bread. Moreover, the bread specific volume decreased from 3.80 to 2.91 and the bake loss content increased from 17.52 to 30.94 with increase in tef flour from 0 to $40 \%$ in composite blends. The sensory attributes scores of the color, aroma, odor, texture and overall acceptability decreased. However, it could be concluded that breads supplemented with $15 \%$ tef flour showed acceptable sensory quality and enhanced nutritionally properties.
\end{abstract}

Keywords: tef; composite flour; gluten; nutritional composition; bread quality

DOI: $10.7176 / \mathrm{FSQM} / 102-03$

Publication date: November $30^{\text {th }} 2020$

\section{Introduction}

Bread is the most widely consumed foodstuff and a substantial part of many cultures and traditions and many people's diets throughout the globe. In Ethiopia, the consumption of wheat based product (bread) is expanding as a result of urbanization. The number of wheat milling and baking industries is increasing.

Bread wheat (Triticum aestivum Desf.) is the preferable raw material for manufacturing baked products with the most desirable end product characteristics. Because of its functional protein (gluten), large loaf volume and fine texture requires formation of well developed and elastic dough structure for making bread. This leads good dough machinability and suited to continuous commercial production which makes good consumer acceptance.

Current consumer preference for baked product has shifting to select healthy food. The need to avail nutritionally enhanced products to make the society nutritionally secure could be addressed through evaluating the feasibility of alternative food crops as a substitute for wheat flour from traditional crop production.

Tef is an indigenous cereal stable crop in Ethiopia which is widely grown in the country ranking the first in terms of area coverage (CSA, 2017). In addition, tef is considered as suitable ingredient in the bakery industry for its good starch gelling properties with small and uniform size of tef starch granules which provides larger surface area and the higher water absorption (Bultosa, 2007; Abebe and Ronda, 2014).

In this respect the enrichment of bread with tef flour show a favorable mineral composition (high in calcium, magnesium and iron), and high in fiber. Tef has high content of dietary fiber and mineral (Stojceska et al., 2010); good balance of all essential amino acid (Gebremariam et al.,2012); high amount of unsaturated fatty acids (mainly Linoleic acid $(18: 2,9,12)$ and $\alpha$-Linolenic acid $(18: 39,12,15)$ (Hager et al., 2012a); gluten free nature and tef is also known for its low glycemic index. Therefore, tef is an ideal candidate to substitute bread wheat partially for the mentioned goals.

The incorporation of tef reached into $20 \%$ and $30 \%$ with wheat for making bread causing lowering the sensory acceptability scores and decreasing physical properties of resulted bread in (Mohammed et al., 2009) and 30\% (Ben-Fayed et al., 2008; Alaunyte et al., 2012) studies, respectively. The addition of tef flour increasing the proportion from 0 to $40 \%$ resulted in decreases in bread volume (Coleman et al., 2013). Hager et al., 2012 observed that $100 \%$ whole-grain white tef flour presents compromised bread sensory quality, and they recommended using it as part of a composite formulation. In addition to using tef for making traditional foods (injera), utilization of tef for other in bakery products (bread) could create alternative product for the consumers and new market for the farmers and processors. The study aims to develop an optimal formulation for producing nutritionally enhanced and healthy bread through incorporation of tef flour by using mixture design without significantly affecting the required bread quality parameters. 


\section{Material and Method}

\section{Grain and Flour preparation}

Tef (variety: DZ-01-96) used in this study was obtained from the 2018/19 main crop production season at DebreZeit Agricultural Research Center (DZARC). Similarly, bread wheat grain (variety: Ogolcha) was taken from the lot produced in the 2018/19 main crop production season at Kulumesa Agricultural Research Center (KARC). These DZ-01-96 and Ogolocha varieties were selected for the formulation because of their popularity and preference of farmer and consumers, and it's very white color and high gluten content, respectively.

Both the tef and bread wheat grains were manually cleaned very carefully by winnowing, sifting and sorting to remove all chaffs, dust and other impurities. The tef grain was ground into whole flour with a laboratory mill (Perten mill 120, Finland) fitted with a $0.5 \mathrm{~mm}$ screen size, while the bread wheat was tempered to $17 \%$ and then milled using a Chopin laboratory mill (Moulin CD1 MILL, Chopin technology, France).

\section{Experimental Formulation and Blending}

Flour blend formulation of the wheat $(60-100) \%$ and tef $(0-40) \%$ flours was conducted by using mixture response surface methodology through D-optimal design (obtained 13 run) for making tef incorporated breads (Table 1). The proportion limit of wheat and tef flours were selected based on earlier reports and preliminary trial. The wheat and tef flours were mixed by rotating drum mixer (Chopin MR 10L, France) to ensure uniform blending. The composite flours were stored in refrigerator at $5^{\circ} \mathrm{C}$ after packing air tight polyethylene bags until needed.

\section{Gluten quality}

The gluten quality of the composite flour sample was evaluated by AACC standard method (AACC, 2000 Method No 38-10). Ten gram of composite sample was weighed and transferred into the glutomatic washing chamber. 4.8 $\mathrm{ml}$ of the $2 \%$ sodium chloride solution was added and allowed for $10 \mathrm{~min}$ in the chamber. Then mixing and washing procedures were proceeded simultaneously. Wet gluten was removed from the washing placed in the centrifuge holder and centrifuged to stop automatically. The passed gluten through the sieve was weighed. The wet gluten content of the composite flour sample was expressed as a percentage of the mass of the original sample. The gluten residue retained inside the screen was weighed and then dried in a Glutrok 2020 heater to give dry gluten. The dry gluten was then weighed.

Water absorption capacity of the flour was determined following methods adopted by Oyeyinka et al., (2013). One gram of flour sample mixed with $10 \mathrm{~mL}$ distilled water for water absorption capacity. The mixture was allowed to stand at room temperature for $30 \mathrm{~min}$ and then centrifuged (Philips Drucker, Oregon, USA) at $3000 \mathrm{~g}$ for $30 \mathrm{~min}$. Water absorption capacity was expressed as gram of water bound per gram flour.

\section{Bread making}

Breads were prepared by a straight-dough production process as indicated in the AACC Method 10-10B (AACC, 2010). The following formula was used for making bread: $300 \mathrm{~g}$ composite flour, $3 \mathrm{~g}$ yeast, $3 \mathrm{~g}$ sugar, $3 \mathrm{~g}$ baking powder and variable water on basis of composite flour water absorption. Bread dough was prepared by mixing $100 \%$ composite flour, $3 \%$ yeast, $2 \%$ salt, $3 \%$ sugarand $60-110 \%$ of water by weight. The dough was then immediately divided and put into baking pans and allowed to ferment or proof for $45 \mathrm{~min}$ in a fermentation cabinet $\left(30^{\circ} \mathrm{C}, 85 \% \mathrm{RH}\right)$ followed by baking $\left(220^{\circ} \mathrm{C}, 15 \mathrm{~min}\right)$ in a preheated baking oven (XFT 115$)$. Bread physical properties were measured after cooling the breads.

\section{Loaf bread volume}

The volume of the breads was determined by the rape seed displacement method as stated in AACC method 1005.01 (AACC, 2010). The loaf was placed in a container of known volume into which rapeseed seeds were run until the container was full. The volume of seeds displaced by the loaf, expressed in cubic centimeters, was considered as the loaf volume.

\section{Nutritional composition}

Proximate composition (moisture, ash, fat and carbohydrate content) of the breads were determined using methods standard (AOAC, 2010). Determination of protein content was performed following the Kjeldahl method procedure. The total dietary fiber was determined based on AOAC Official methods (AOAC 985.29). Mineral composition of the breads were determined using the method described in AOAC (1990). The samples were analyzed from nitric acid-hydrogen peroxide digest using Inductively Coupled Plasma Atomic Emission Spectrometry (ICPAES).

\section{Sensory evaluation}

The sensory qualities of the breads prepared from the different composite flours were evaluated by using 20 untrained participants. A five point hedonic scale was employed to estimate the sensory acceptability and 
preferences of the participants. The attributes assessed included: visual color, taste, aroma, mouth feel, texture and over all acceptance.

\section{Statistical analysis}

Design Expert 7.1 was used to generate surface response plots that permitted to quantify the effects of different independent variables on the selected dependent variables $(\mathrm{p}<0.05)$. All the measured parameters were replicated three times. Analysis of Variance (One-way ANOVA), followed by Duncan post hoc test, was performed to determine significant differences between bread samples made from composite flours by SPSS 20 .

\section{Results and Discussion}

\section{Composite flour characteristics}

The composite flour characteristics wheat flour and whole tef flour blends are shown in Table 1. In baking, optimum quantity of wet gluten is desirable for developing the required viscoelastic dough leading to a bread with the desired physical and sensorial quality. Wet and dry gluten content in the composite flours significantly decreased by $53 \%$ and $47 \%$ with increasing tef flour levels from $0-40 \%$, respectively. Control (100\% wheat flour) had the highest wet gluten $(29.83 \%)$ and dry gluten $(12.03 \%)$ content while maximum tef substitution $(40 \%$ tef flour) had the lowest wet $(14.00 \%)$ and dry $(6.37 \%)$ gluten levels of composite flour. This could be due the fact that tef flour is gluten free which diluted of the gluten in the wheat (Hopman et al, 2007; 7 Mohammed et al., 2009).

Water absorption capacity was lowest in control wheat flour $(57.65 \%)$, while increased levels were detected in highest tef flour (35-40\%) incorporation levels $(97 \%)$. The tiny size of the tef starch granule which has larger bulk surface area could have contributed for the higher water absorption capacity of the tef incorporated composite flours (Bultossa et al., 2007; Abebe et al., 2015). White and brown tef in the composite flours were no significant differences in water absorption capacity, wet and dry gluten through $10 \%$ and $20 \%$ incorporation levels. Table 1. Measured flour characteristics

\begin{tabular}{llllll}
\hline \multirow{2}{*}{ Run } & \multicolumn{4}{l}{ Flour ratio } & \multicolumn{3}{l|}{ Gluten and WAC Characteristics of Composites } \\
\cline { 2 - 5 } & WT & BW & Wet gluten $(\%)$ & Dry gluten $(\%)$ & WAC $(\%)$ \\
\hline $\mathbf{1}$ & 0 & 100 & $29.83 \pm 0.33^{\mathrm{a}}$ & $12.03 \pm 0.09 \mathrm{a}$ & $59.00 \pm 2.09^{\mathrm{ef}}$ \\
$\mathbf{2}$ & 40 & 60 & $14.00 \pm 0.00^{\mathrm{g}}$ & $6.37 \pm 0.13^{\mathrm{i}}$ & $95.67 \pm 1.21^{\mathrm{a}}$ \\
$\mathbf{3}$ & 40 & 60 & $14.09 \pm 0.00^{\mathrm{g}}$ & $6.63 \pm 0.18^{\mathrm{i}}$ & $96.33 \pm 1.33^{\mathrm{a}}$ \\
$\mathbf{4}$ & 20 & 80 & $20.67 \pm 0.33^{\mathrm{d}}$ & $9.70 \pm 0.06^{\mathrm{d}}$ & $69.33 \pm 2.33^{\mathrm{c}}$ \\
$\mathbf{5}$ & 0 & 100 & $29.33 \pm 0.33^{\mathrm{a}}$ & $11.83 \pm 0.19^{\mathrm{a}}$ & $57.67 \pm 1.45^{\mathrm{f}}$ \\
$\mathbf{6}$ & 34.9 & 65.1 & $15.00 \pm 0.00^{\mathrm{f}}$ & $7.03 \pm 0.09^{\mathrm{h}}$ & $97.00 \pm 1.16^{\mathrm{a}}$ \\
$\mathbf{7}$ & 20 & 80 & $21.00 \pm 0.58^{\mathrm{d}}$ & $9.53 \pm 0.09^{\mathrm{de}}$ & $68.33 \pm 1.67^{\mathrm{cd}}$ \\
$\mathbf{8}$ & 0 & 100 & $29.33 \pm 0.33^{\mathrm{a}}$ & $11.93 \pm 0.07^{\mathrm{a}}$ & $58.00 \pm 1.53^{\mathrm{f}}$ \\
$\mathbf{9}$ & 25 & 75 & $21.00 \pm 0.00^{\mathrm{d}}$ & $8.90 \pm 0.12^{\mathrm{f}}$ & $78.34 \pm 1.67^{\mathrm{b}}$ \\
$\mathbf{1 0}$ & 5 & 95 & $27.00 \pm 0.00^{\mathrm{b}}$ & $11.13 \pm 0.12^{\mathrm{b}}$ & $63.33 \pm 1.67^{\mathrm{de}}$ \\
$\mathbf{1 1}$ & 10.2 & 89.2 & $24.00 \pm 0.00^{\mathrm{c}}$ & $10.77 \pm 0.15^{\mathrm{bc}}$ & $70.67 \pm 2.19^{\mathrm{c}}$ \\
$\mathbf{1 2}$ & 30 & 70 & $16.00 \pm 0.00^{\mathrm{e}}$ & $7.93 \pm 0.09^{\mathrm{g}}$ & $76.67 \pm 1.67^{\mathrm{b}}$ \\
$\mathbf{1 3}$ & 40 & 60 & $13.89 \pm 0.00^{\mathrm{g}}$ & $6.70 \pm 0.20^{\mathrm{hi}}$ & $95.33 \pm 1.45^{\mathrm{a}}$ \\
\hline & BT & BW & & & $71.01 \pm 2.08^{\mathrm{c}}$ \\
\hline $\mathbf{1 4}$ & 10 & 90 & $24.00 \pm 0.00^{\mathrm{c}}$ & $10.43 \pm 0.15^{\mathrm{c}}$ & $71.00 \pm 2.08^{\mathrm{c}}$ \\
$\mathbf{1 5}$ & 20 & 80 & $20.33 \pm 0.33^{\mathrm{d}}$ & $9.30 \pm 0.10^{\mathrm{e}}$ \\
\hline
\end{tabular}

Values followed by different letters with in a column indicate significant difference $(\mathrm{p}<0.05)$. All values are expressed as mean \pm SE in triplicate; WAC: Water absorption capacity; WT- White Tef; BT- Brown Tef; BWBread Wheat

\section{Bread physical characteristics}

Incorporation of tef flours to the wheat flour significantly $(\mathrm{p}<0.05)$ affected the measured bread characteristics (Table 2). The specific volume of tef breads containing different blending proportions are shown in Table 2 . The composite bread differed statistically in weight, volume, specific volume and bake loss for both brown and white tef flour. Bake loss was lowest in bread wheat flour, while increased levels were detected with $20 \%$ tef flour incorporation levels.

The specific volume values of the $0-40 \%$ tef incorporated breads narrowly ranged from $2.91-3.80 \mathrm{~mL} / \mathrm{g}$. There were no statistical difference $(\mathrm{p}<0.05)$ between the white bread and $25 \%$ tef whole grain flour incorporate bread samples, which had an average specific volume of $3.10 \mathrm{~mL} / \mathrm{g}$, and $3.11 \mathrm{~mL} / \mathrm{g}$, respectively. Incorporated $10 \%$ and $20 \%$ of white and brown tef in bread making were significant difference in specific volume, in which brown tef higher than white one. The largest effect on specific volume reduction was observed in the use of highest tef incorporation levels, presenting $2.91 \mathrm{~mL} / \mathrm{g}$. 
Table 2: Measure bread physical parameters

\begin{tabular}{|c|c|c|c|c|c|c|}
\hline \multirow{2}{*}{ Run } & \multicolumn{2}{|c|}{ Flour ratio } & \multicolumn{4}{|c|}{ Physical Properties of Bread } \\
\hline & WT & BW & Weight $(\mathrm{g})$ & Volume $\left(\mathrm{cm}^{3}\right)$ & Spec.volume $\left(\mathrm{cm}^{3} / \mathrm{g}\right)$ & Bake loss $(\mathrm{g})$ \\
\hline 1 & 0 & 100 & $130.31 \pm 0.41^{\mathrm{a}}$ & $406.19 \pm 0.28^{\mathrm{d}}$ & $3.10 \pm 0.00^{\mathrm{g}}$ & $17.55 \pm 0.20^{\mathrm{i}}$ \\
\hline 2 & 40 & 60 & $123.06 \pm 0.10^{\mathrm{e}}$ & $369.67 \pm 0.38^{\mathrm{h}}$ & $3.00 \pm 0.05^{\mathrm{h}}$ & $25.85 \pm 0.18^{\mathrm{cd}}$ \\
\hline 3 & 40 & 60 & $123.43 \pm 0.26^{\mathrm{e}}$ & $368.61 \pm 0.36^{\mathrm{h}}$ & $3.00 \pm 0.01^{\mathrm{h}}$ & $25.24 \pm 0.25^{\mathrm{cde}}$ \\
\hline 4 & 20 & 80 & $116.75 \pm 0.22^{\mathrm{hl}}$ & $410.26 \pm 0.22^{\mathrm{c}}$ & $3.50 \pm 0.05^{\mathrm{d}}$ & $30.18 \pm 0.43^{\mathrm{a}}$ \\
\hline 5 & 0 & 100 & $130.03 \pm 0.34^{\mathrm{a}}$ & $406.17 \pm 0.22^{\mathrm{d}}$ & $3.10 \pm 0.00^{\mathrm{g}}$ & $17.58 \pm 0.17^{\mathrm{i}}$ \\
\hline 6 & 34.9 & 65.1 & $124.57 \pm 0.25^{\mathrm{d}}$ & $383.38 \pm 0.41^{\mathrm{g}}$ & $3.10 \pm 0.00^{\mathrm{g}}$ & $24.42 \pm 0.28^{\mathrm{def}}$ \\
\hline 7 & 20 & 80 & $115.71 \pm 0.21^{1}$ & $409.61 \pm 0.37^{\mathrm{c}}$ & $3.53 \pm 0.03^{\mathrm{d}}$ & $30.94 \pm 0.38$ \\
\hline 8 & 0 & 100 & $129.80 \pm 0.14^{\mathrm{a}}$ & $406.29 \pm 0.25^{\mathrm{d}}$ & $3.10 \pm 0.01^{\mathrm{g}}$ & $17.52 \pm 0.13^{\mathrm{i}}$ \\
\hline 9 & 25 & 75 & $130.18 \pm 0.22^{\mathrm{a}}$ & $400.86 \pm 0.51^{\mathrm{e}}$ & $3.11 \pm 0.00^{\mathrm{g}}$ & $19.82 \pm 0.10^{\mathrm{h}}$ \\
\hline 10 & 5 & 95 & $126.01 \pm 0.08^{c}$ & $449.43 \pm 0.27^{\mathrm{a}}$ & $3.60 \pm 0.01^{\mathrm{c}}$ & $20.79 \pm 0.28^{g}$ \\
\hline 11 & 10.2 & 89.2 & $121.63 \pm 0.21^{\mathrm{f}}$ & $448.47 \pm 0.29^{\mathrm{ab}}$ & $3.70 \pm 0.00^{\mathrm{b}}$ & $24.86 \pm 0.22^{\mathrm{de}}$ \\
\hline 12 & 30 & 70 & $123.48 \pm 0.26^{\mathrm{e}}$ & $391.30 \pm 0.56^{\mathrm{f}}$ & $3.20 \pm 0.00^{\mathrm{f}}$ & $24.07 \pm 0.32^{\mathrm{ef}}$ \\
\hline \multirow[t]{2}{*}{13} & 40 & 60 & $129.11 \pm 0.16^{\mathrm{bc}}$ & $368.58 \pm 0.37^{\mathrm{h}}$ & $2.91 \pm 0.03^{\mathrm{hi}}$ & $24.00 \pm 0.12^{\mathrm{ef}}$ \\
\hline & RT & $\mathrm{BW}$ & & & & \\
\hline 14 & 10 & 90 & $118.28 \pm 0.29^{g}$ & $447.61 \pm 0.33^{b}$ & $3.80 \pm 0.00^{\mathrm{a}}$ & $28.14 \pm 0.26^{\mathrm{b}}$ \\
\hline 15 & 20 & 80 & $118.68 \pm 0.16^{\mathrm{g}}$ & $409.54 \pm 0.49^{c}$ & $3.43 \pm 0.03^{\mathrm{e}}$ & $30.40 \pm 0.46^{\mathrm{a}}$ \\
\hline
\end{tabular}

Values followed by different letters with in a column indicate significant difference $(p<0.05)$. All values are expressed as mean \pm SE in triplicate; WAC: Water absorption capacity; Spec. volume: Specific volume, WT: Wheat Tef; RT- Red Tef; BW- Bread Wheat

This effect reflects the greater impact on the gluten network due to the action of the fibers, which leads to a decrease in gas retention capacity, resulting in reduction in the specific volume of the breads (Gómez et al., 2003). The mean specific volume found in this study is consistent with those reported by Mohammed et al.,(2005), who found a mean value of $3.88 \mathrm{~mL} / \mathrm{g}$ from $0-20 \%$ incorporated tef breads. The substituted tef flour contain high amount of fiber that may also affect the specific volume. The addition of whole grain generally weakens the structure of the bread by reducing the volume and elasticity of the crumb (Salmenkallio-Marttila et al., 2001).

\section{Bread proximate composition}

The proximate composition of breads made from refined wheat flour and whole tef flour blends are shown in Table 3.The moisture content increases from 5.15 to $6.31 \%$ with increase in percentage tef grain flour $(0$ to $40 \%)$ in composite bread. The increase in moisture content with increase in tef grain flour could be due to the extremely small particles size of the flour and due to high fiber content in tef flour which enhances water absorption in tef flour (Bultosa and Taylor, 2004; Abebe et al., 2015).

The formulated bread ash and fiber content doubled upon blending wheat with tef flours $(0-40 \%)$ in Table 3. This could be due to the higher ash and fiber content of tef flour (1.85-3.06 g/100g and 2.6-3.8 g/100g, respectively) and this is because of the fact that tef has small grain size and it is always whole floured (Bultosa, 2007; Baye, 2014) The results are also in agreement with the earlier works reported by Mohammed et al (2009) and Hager et al.(2012). 
Table 3: Proximate composition of bread from composite tef and wheat flour

\begin{tabular}{|c|c|c|c|c|c|c|c|}
\hline \multirow[t]{2}{*}{ Run } & \multicolumn{7}{|c|}{ Proximate composition $(\mathrm{g} / 100 \mathrm{~g})$} \\
\hline & Moisture & Total ash & Crude protein & Crude fat & Carbohydrate & Crude fiber & Energy \\
\hline 1 & $5.31 \pm 0.02^{\mathrm{gh}}$ & $1.03 \pm 0.02^{\mathrm{i}}$ & $9.73 \pm 0.04^{\mathrm{de}}$ & $1.09 \pm 0.04^{f}$ & $82.84 \pm 0.04^{\mathrm{ab}}$ & $1.00 \pm 0.07^{\mathrm{f}}$ & $380.07 \pm 0.18^{c}$ \\
\hline 2 & $6.28 \pm 0.04^{\mathrm{a}}$ & $1.91 \pm 0.01^{\mathrm{a}}$ & $10.87 \pm 0.04^{\mathrm{ab}}$ & $1.76 \pm 0.05^{\mathrm{ab}}$ & $79.18 \pm 0.03^{\mathrm{h}}$ & $1.92 \pm 0.09^{\mathrm{a}}$ & $376.01 \pm 0.34^{\mathrm{h}}$ \\
\hline 3 & $6.31 \pm 0.02^{\mathrm{a}}$ & $1.80 \pm 0.01^{b}$ & $10.96 \pm 0.14^{\mathrm{a}}$ & $1.64 \pm 0.03^{b}$ & $79.19 \pm 0.09^{\mathrm{h}}$ & $1.99 \pm 0.06^{\mathrm{a}}$ & $375.72 \pm 0.16^{\mathrm{h}}$ \\
\hline 4 & $5.52 \pm 0.01^{\mathrm{f}}$ & $1.38 \pm 0.02^{\mathrm{e}}$ & $9.94 \pm 0.02^{\mathrm{cd}}$ & $1.80 \pm 0.07^{\mathrm{a}}$ & $81.36 \pm 0.01^{\mathrm{e}}$ & $1.42 \pm 0.08^{\mathrm{d}}$ & $381.36 \pm 0.59^{\mathrm{a}}$ \\
\hline 5 & $5.15 \pm 0.01^{\mathrm{h}}$ & $1.07 \pm 0.03^{\mathrm{i}}$ & $9.83 \pm 0.02^{\mathrm{cd}}$ & $1.06 \pm 0.04^{\mathrm{f}}$ & $82.82 \pm 0.04^{\mathrm{ab}}$ & $0.92 \pm 0.02^{\mathrm{f}}$ & $380.82 \pm 0.17^{\mathrm{f}}$ \\
\hline 6 & $6.08 \pm 0.06^{\mathrm{c}}$ & $1.82 \pm 0.02^{\mathrm{d}}$ & $10.73 \pm 0.14^{\mathrm{b}}$ & $1.80 \pm 0.01^{\mathrm{a}}$ & $79.56 \pm 0.18^{g}$ & $1.84 \pm 0.09^{\mathrm{b}}$ & $377.39 \pm 0.08^{f}$ \\
\hline 7 & $5.43 \pm 0.05^{\mathrm{f}}$ & $1.36 \pm 0.00^{\mathrm{ef}}$ & $9.89 \pm 0.05^{\mathrm{cd}}$ & $1.74 \pm 0.03^{\mathrm{ab}}$ & $81.57 \pm 0.09^{\mathrm{de}}$ & $1.39 \pm 0.05^{\mathrm{de}}$ & $381.05 \pm 0.55^{\mathrm{a}}$ \\
\hline 8 & $5.22 \pm 0.02^{\mathrm{gh}}$ & $1.05 \pm 0.03^{\mathrm{i}}$ & $9.74 \pm 0.03^{\mathrm{de}}$ & $1.08 \pm 0.04^{f}$ & $82.92 \pm 0.07^{\mathrm{a}}$ & $0.97 \pm 0.06^{\mathrm{f}}$ & $380.32 \pm 0.12^{\mathrm{ab}}$ \\
\hline 9 & $5.67 \pm 0.05^{\mathrm{e}}$ & $1.59 \pm 0.01^{\mathrm{c}}$ & $9.95 \pm 0.03^{\mathrm{cd}}$ & $1.51 \pm 0.01^{\mathrm{c}}$ & $81.28 \pm 0.07^{\mathrm{e}}$ & $1.65 \pm 0.07^{\mathrm{c}}$ & $378.53 \pm 0.28^{d}$ \\
\hline 10 & $5.23 \pm 0.07^{c}$ & $1.17 \pm 0.01^{\mathrm{h}}$ & $9.84 \pm 0.04^{\mathrm{cd}}$ & $1.23 \pm 0.02^{\mathrm{e}}$ & $82.53 \pm 0.10^{\mathrm{b}}$ & $1.31 \pm 0.09^{\mathrm{e}}$ & $380.58 \pm 0.74^{\mathrm{ab}}$ \\
\hline 11 & $5.35 \pm 0.04^{\mathrm{g}}$ & $1.26 \pm 0.01^{\mathrm{g}}$ & $9.93 \pm 0.05^{\mathrm{cd}}$ & $1.36 \pm 0.04^{\mathrm{d}}$ & $82.13 \pm 0.15^{c}$ & $1.29 \pm 0.02^{\mathrm{e}}$ & $380.47 \pm 0.27^{\mathrm{ab}}$ \\
\hline 12 & $5.91 \pm 0.01^{\mathrm{d}}$ & $1.82 \pm 0.01^{b}$ & $10.10 \pm 0.02^{c}$ & $1.52 \pm 0.02^{\mathrm{c}}$ & $80.65 \pm 0.03^{\mathrm{f}}$ & $1.70 \pm 0.06^{\mathrm{c}}$ & $376.63 \pm 0.09^{\mathrm{g}}$ \\
\hline 13 & $6.20 \pm 0.03^{\mathrm{ab}}$ & $1.95 \pm 0.03^{\mathrm{a}}$ & $10.08 \pm 0.21^{\mathrm{a}}$ & $1.83 \pm 0.03^{\mathrm{a}}$ & $78.94 \pm 0.19^{\mathrm{h}}$ & $2.01 \pm 0.06^{\mathrm{a}}$ & $376.55 \pm 0.95^{\mathrm{g}}$ \\
\hline 14 & $5.98 \pm 0.04^{\mathrm{cd}}$ & $1.32 \pm 0.05^{\mathrm{f}}$ & $9.53 \pm 0.16^{\mathrm{e}}$ & $1.44 \pm 0.02^{\mathrm{d}}$ & $81.73 \pm 0.16^{\mathrm{d}}$ & $1.22 \pm 0.05^{\mathrm{ef}}$ & $377.95 \pm 0.18^{\mathrm{e}}$ \\
\hline 15 & $5.65 \pm 0.03^{\mathrm{e}}$ & $1.50 \pm 0.04^{\mathrm{d}}$ & $8.90 \pm 0.01^{\mathrm{f}}$ & $1.81 \pm 0.03^{\mathrm{a}}$ & $82.13 \pm 0.04^{c}$ & $1.39 \pm 0.09^{\mathrm{de}}$ & $380.45 \pm 0.20^{\mathrm{ab}}$ \\
\hline
\end{tabular}

Notes: Values are mean and standard error of each run. Values followed by different letters with in a column indicate significant difference $(p<0.05)$.

The fat content of the produced bread prepared from the composite flours significantly increased to $72.64 \%$ from control wheat flour to maximum tef substitution levels. This could be due to whole floured which contain the germ in the tef and significantly higher fat content in tef than wheat flours (Abebe et al., 2015).

The mean carbohydrate contents of the formulated breads significantly decreased by $4.8 \%$ when the proportion of tef in composite flour increased from $0-40 \%$. This could be due to higher carbohydrate composition of refined wheat flour than tef flours. This lowering carbohydrate in the composite flours selected for blending of tef with wheat emphasize decreasing glycemic response of the bread to be obtained.

\section{Bread mineral content}

The mineral content of the blend bread made with the composite flour from wheat and tef was shown in Table 3 . Blending of tef and wheat had a significant effect $(\mathrm{P}<0.05)$ on the mineral content of bread. Control bread samples (100\% wheat flour) had the lowest in iron, calcium, manganese, zinc, magnesium, potassium and sodium; and also the highest in all mineral content was obtained for bread with maximum tef proportion (40\% tef). The $\mathrm{Ca}, \mathrm{Fe}, \mathrm{Mn}$, $\mathrm{Zn}, \mathrm{Mg}, \mathrm{K}$ and $\mathrm{Na}$ result shown that the variation percent is at $5 \%$ and $40 \%$ tef flour addition were $69 \%, 75 \%$, $56.69 \%, 18.65 \%, 59.22 \%, 30.96 \%$ and $51.43 \%$, respectively. Higher mineral contentment in the tef incorporated breads could be due to the availability of high mineral content in tef flour than the wheat flour (Bultosa, 2007; Abebe et al., 2015).

Table 4: Mineral content of bread from composite tef and wheat flour

\begin{tabular}{|c|c|c|c|c|c|c|c|}
\hline \multirow[t]{2}{*}{ Run } & \multicolumn{7}{|c|}{ Mineral composition (mg/100g) } \\
\hline & $\mathrm{Ca}$ & $\mathrm{Fe}$ & $\mathrm{Mn}$ & $\mathrm{Zn}$ & $\mathrm{Mg}$ & $\mathrm{K}$ & $\mathrm{Na}$ \\
\hline 1 & $18.92 \pm 0.17^{j}$ & $1.45 \pm 0.04^{j}$ & $1.22 \pm 0.03^{\mathrm{h}}$ & $2.05 \pm 0.04^{\mathrm{ef}}$ & $32.63 \pm 0.39^{\mathrm{k}}$ & $167.86 \pm 0.19^{\mathrm{hi}}$ & $2.49 \pm 0.01^{\mathrm{j}}$ \\
\hline 2 & $76.11 \pm 1.46^{\mathrm{a}}$ & $7.94 \pm 0.11^{\mathrm{ab}}$ & $3.14 \pm 0.03^{\mathrm{a}}$ & $2.48 \pm 0.03^{\mathrm{a}}$ & $85.18 \pm 0.17^{\mathrm{ab}}$ & $245.44 \pm 1.29^{\mathrm{a}}$ & $5.58 \pm 0.03^{\mathrm{a}}$ \\
\hline 3 & $74.91 \pm 1.66^{\mathrm{a}}$ & $7.93 \pm 0.02^{\mathrm{ab}}$ & $3.08 \pm 0.01^{\mathrm{a}}$ & $2.51 \pm 0.03^{\mathrm{a}}$ & $85.79 \pm 0.23^{\mathrm{ab}}$ & $244.81 \pm 0.31^{\mathrm{ab}}$ & $5.53 \pm 0.04^{\mathrm{ab}}$ \\
\hline 4 & $50.31 \pm 0.42^{\mathrm{ef}}$ & $4.83 \pm 0.04^{\mathrm{f}}$ & $2.02 \pm 0.04^{\mathrm{e}}$ & $2.23 \pm 0.03^{c}$ & $57.99 \pm 0.10^{\mathrm{g}}$ & $205.35 \pm 0.57^{\mathrm{f}}$ & $4.06 \pm 0.05^{\mathrm{f}}$ \\
\hline 5 & $19.19 \pm 0.20^{\mathrm{j}}$ & $1.44 \pm 0.03^{j}$ & $1.17 \pm 0.01^{\mathrm{h}}$ & $2.00 \pm 0.01^{\mathrm{f}}$ & $33.02 \pm 0.37^{\mathrm{k}}$ & $167.94 \pm 1.05^{\mathrm{hi}}$ & $2.48 \pm 0.01^{\mathrm{j}}$ \\
\hline 6 & $66.12 \pm 0.23^{b}$ & $7.40 \pm 0.04^{b c}$ & $2.86 \pm 0.02^{b}$ & $2.44 \pm 0.03^{\mathrm{a}}$ & $81.00 \pm 0.09^{b c}$ & $229.38 \pm 0.75^{\mathrm{bc}}$ & $5.24 \pm 0.03^{b c}$ \\
\hline 7 & $51.33 \pm 0.64^{\mathrm{de}}$ & $4.80 \pm 0.02^{\mathrm{f}}$ & $2.00 \pm 0.01^{\mathrm{e}}$ & $2.21 \pm 0.02^{\mathrm{cd}}$ & $57.75 \pm 0.43^{\mathrm{g}}$ & $204.62 \pm 0.38^{\mathrm{f}}$ & $4.05 \pm 0.02^{\mathrm{f}}$ \\
\hline 8 & $18.30 \pm 0.73^{\mathrm{j}}$ & $1.48 \pm 0.05^{\mathrm{j}}$ & $1.15 \pm 0.05^{\mathrm{h}}$ & $1.99 \pm 0.04^{\mathrm{f}}$ & $32.32 \pm 0.56^{\mathrm{k}}$ & $165.99 \pm 0.90^{\mathrm{i}}$ & $2.51 \pm 0.03^{j}$ \\
\hline 9 & $52.93 \pm 0.07^{d}$ & $4.93 \pm 0.06^{\mathrm{f}}$ & $2.48 \pm 0.02^{\mathrm{d}}$ & $2.27 \pm 0.03^{b c}$ & $64.33 \pm 0.06^{\mathrm{e}}$ & $215.93 \pm 0.57^{\mathrm{e}}$ & $4.50 \pm 0.02^{\mathrm{e}}$ \\
\hline 10 & $23.25 \pm 0.23^{\mathrm{i}}$ & $2.02 \pm 0.03^{\mathrm{i}}$ & $1.36 \pm 0.04^{\mathrm{g}}$ & $2.05 \pm 0.04^{\mathrm{ef}}$ & $34.98 \pm 0.12^{\mathrm{j}}$ & $169.44 \pm 0.45^{\mathrm{h}}$ & $2.71 \pm 0.03^{\mathrm{i}}$ \\
\hline 11 & $29.68 \pm 0.23^{\mathrm{h}}$ & $2.82 \pm 0.07^{\mathrm{h}}$ & $1.59 \pm 0.03^{\mathrm{f}}$ & $2.07 \pm 0.06^{\mathrm{ef}}$ & $44.00 \pm 0.33^{\mathrm{i}}$ & $186.25 \pm 0.36^{\mathrm{g}}$ & $3.32 \pm 0.04^{h}$ \\
\hline 12 & $55.49 \pm 0.05^{\mathrm{c}}$ & $6.82 \pm 0.04^{\mathrm{d}}$ & $2.72 \pm 0.04^{\mathrm{c}}$ & $2.33 \pm 0.04^{b}$ & $69.91 \pm 0.13^{\mathrm{d}}$ & $219.96 \pm 0.10^{\mathrm{d}}$ & $4.82 \pm 0.04^{\mathrm{d}}$ \\
\hline 13 & $75.22 \pm 0.18^{a}$ & $8.12 \pm 0.13^{\mathrm{ab}}$ & $3.01 \pm 0.12^{\mathrm{a}}$ & $2.52 \pm 0.03^{\mathrm{a}}$ & $84.44 \pm 0.45^{\mathrm{ab}}$ & $243.31 \pm 0.32^{\mathrm{ab}}$ & $5.47 \pm 0.04^{\mathrm{ab}}$ \\
\hline 14 & $35.72 \pm 0.16^{\mathrm{g}}$ & $3.40 \pm 0.02^{\mathrm{g}}$ & $1.69 \pm 0.04^{\mathrm{f}}$ & $2.12 \pm 0.03^{\mathrm{de}}$ & $45.29 \pm 0.16^{\mathrm{h}}$ & $184.52 \pm 0.47^{\mathrm{g}}$ & $3.38 \pm 0.05^{\mathrm{h}}$ \\
\hline 15 & $48.77 \pm 0.08^{\mathrm{f}}$ & $5.22 \pm 0.04^{\mathrm{e}}$ & $2.06 \pm 0.05^{\mathrm{e}}$ & $2.45 \pm 0.04^{\mathrm{a}}$ & $59.00 \pm 0.12^{\mathrm{f}}$ & $204.53 \pm 0.54^{f}$ & $3.94 \pm 0.05^{\mathrm{g}}$ \\
\hline
\end{tabular}

Notes: Values are mean and standard error of each run. Values followed by different letters with in a column indicate significant difference $(p<0.05)$. 


\section{Bread Sensory Quality}

Blend ratio had a significant impact $(\mathrm{p}<0.05)$ on the sensory acceptance of the composite bread among the 15 experimental formulations based on panelist preference. As shown in Table 5, as the proportion of tef flour increased, bread color, aroma, taste, mouth feel, texture and overall acceptability of the breads decreased significantly. With increasing tef incorporation levels (0-40\%) bread color scores decreased from 5.00 to 3.16 with increase in added tef grain flour. Such detrimental effect could be related to the fact that the tef flour was a whole flour (Bultosa, 2007).

Similarly composite bread flavor mean score decreased from 4.63 to 2.95 (aroma) and 4.47 to 3.05 (taste). The different flavor of the composite breads could be because of the different intrinsic flavor difference that tef flour has (Mohammed et al; 2009 and Hager et al., 2012).

Table 4: Sensory acceptability of formulated bread from composite tef and wheat flour

\begin{tabular}{|c|c|c|c|c|c|c|}
\hline \multirow[t]{2}{*}{ Formulation } & \multicolumn{6}{|c|}{ Sensory attribute } \\
\hline & Color & Aroma & Taste & Mouth feel & Texture & $\mathrm{OAA}$ \\
\hline 1 & $5.00 \pm 0.00^{\mathrm{a}}$ & $4.63 \pm 0.11^{\mathrm{a}}$ & $4.42 \pm 0.14^{\mathrm{a}}$ & $4.68 \pm 0.11^{\mathrm{a}}$ & $4.74 \pm 0.13^{\mathrm{a}}$ & $4.84 \pm 0.09^{a}$ \\
\hline 2 & $3.21 \pm 0.20^{\mathrm{f}}$ & $3.16 \pm 0.12^{\mathrm{de}}$ & $3.42 \pm 0.26^{\mathrm{def}}$ & $3.26 \pm 0.21^{\mathrm{efg}}$ & $2.95 \pm 0.20^{\mathrm{gh}}$ & $3.21 \pm 0.20^{\mathrm{def}}$ \\
\hline 3 & $3.16 \pm 0.22^{\mathrm{f}}$ & $3.26 \pm 0.23^{\text {cde }}$ & $3.11 \pm 0.22^{\mathrm{efg}}$ & $2.84 \pm 0.21^{\mathrm{gh}}$ & $3.16 \pm 0.16^{\mathrm{fg}}$ & $3.00 \pm 0.15^{\mathrm{ef}}$ \\
\hline 4 & $4.42 \pm 0.18^{\mathrm{abc}}$ & $4.16 \pm 0.18^{\mathrm{ab}}$ & $4.11 \pm 0.20^{\mathrm{abcd}}$ & $3.79 \pm 0.18^{\mathrm{cde}}$ & $3.95 \pm 0.20^{\mathrm{bcd}}$ & $4.00 \pm 0.19^{b c}$ \\
\hline 5 & $4.95 \pm 0.05^{\mathrm{a}}$ & $4.53 \pm 0.14^{\mathrm{a}}$ & $4.42 \pm 0.21^{\mathrm{a}}$ & $4.53 \pm 0.16^{\mathrm{ab}}$ & $4.63 \pm 0.11^{\mathrm{a}}$ & $4.74 \pm 0.13^{\mathrm{a}}$ \\
\hline 6 & $3.68 \pm 0.20^{\mathrm{def}}$ & $3.32 \pm 0.22^{\text {cde }}$ & $3.26 \pm 0.21^{\mathrm{ef}}$ & $3.47 \pm 0.25^{\mathrm{defg}}$ & $3.53 \pm 0.21^{\mathrm{defg}}$ & $3.53 \pm 0.23^{\text {cde }}$ \\
\hline 7 & $4.17 \pm 0.18^{\text {bcef }}$ & $3.74 \pm 0.25^{\mathrm{bcd}}$ & $3.58 \pm 0.23^{\text {cdef }}$ & $3.63 \pm 0.21^{\mathrm{de}}$ & $3.74 \pm 0.20^{\text {cdef }}$ & $3.63 \pm 0.19^{\mathrm{cd}}$ \\
\hline 8 & $4.91 \pm 0.17^{\mathrm{a}}$ & $4.56 \pm 0.20^{\mathrm{a}}$ & $4.47 \pm 0.11^{\mathrm{a}}$ & $4.61 \pm 0.09^{\mathrm{a}}$ & $4.59 \pm 0.09^{\mathrm{a}}$ & $4.77 \pm 0.15^{\mathrm{a}}$ \\
\hline 9 & $3.74 \pm 0.17^{\mathrm{def}}$ & $3.31 \pm 0.20^{\text {cde }}$ & $3.63 \pm 0.21^{\text {bcdef }}$ & $3.58 \pm 0.22^{\mathrm{def}}$ & $3.74 \pm 0.19^{\text {cdef }}$ & $3.68 \pm 0.17^{\mathrm{cd}}$ \\
\hline 10 & $4.47 \pm 0.12^{\mathrm{ab}}$ & $4.42 \pm 0.12^{\mathrm{a}}$ & $4.32 \pm 0.15^{\mathrm{ab}}$ & $4.32 \pm 0.20^{\mathrm{abc}}$ & $4.26 \pm 0.20^{\mathrm{abc}}$ & $4.47 \pm 0.14^{\mathrm{ab}}$ \\
\hline 11 & $4.79 \pm 0.12^{\mathrm{a}}$ & $4.16 \pm 0.21^{\mathrm{ab}}$ & $4.16 \pm 0.21^{\mathrm{abc}}$ & $4.05 \pm 0.20^{\mathrm{bcd}}$ & $4.47 \pm 0.16^{\mathrm{ab}}$ & $4.42 \pm 0.16^{\mathrm{ab}}$ \\
\hline 12 & $3.95 \pm 0.20^{\mathrm{bcd}}$ & $3.53 \pm 0.21^{\mathrm{cde}}$ & $3.79 \pm 0.24^{\mathrm{abcde}}$ & $3.74 \pm 0.20^{\text {cde }}$ & $3.74 \pm 0.21^{\text {cdef }}$ & $3.68 \pm 0.17^{\mathrm{cd}}$ \\
\hline 13 & $3.21 \pm 0.18^{\mathrm{f}}$ & $2.95 \pm 0.14^{\mathrm{ef}}$ & $3.05 \pm 0.22^{\mathrm{fg}}$ & $2.95 \pm 0.20^{\mathrm{fgh}}$ & $3.21 \pm 0.16^{\mathrm{efg}}$ & $2.95 \pm 0.14^{\mathrm{f}}$ \\
\hline 14 & $3.90 \pm 0.23^{\mathrm{cde}}$ & $3.84 \pm 0.20^{\mathrm{bc}}$ & $3.68 \pm 0.24^{\text {bcdef }}$ & $3.58 \pm 0.18^{\mathrm{def}}$ & $3.79 \pm 0.24^{\text {cde }}$ & $3.84 \pm 0.19^{c}$ \\
\hline 15 & $3.32 \pm 0.30^{\mathrm{ef}}$ & $3.53 \pm 0.25^{\mathrm{cde}}$ & $3.58 \pm 0.26^{\text {cdef }}$ & $3.26 \pm 0.27^{\mathrm{efg}}$ & $3.26 \pm 0.25^{\mathrm{efg}}$ & $3.47 \pm 0.28^{\text {cdef }}$ \\
\hline Mean & 4.07 & 3.83 & 3.83 & 3.8 & 3.9 & 3.92 \\
\hline C.V. $(\%)$ & 6.61 & 4.28 & 4.38 & 4.6 & 3.8 & 3.74 \\
\hline
\end{tabular}

Notes: Values are mean and standard error of each run. Values followed by different letters with in a column indicate significant difference $(p<0.05)$.

The mean texture score of the composite breads decreased from 4.74 to 2.95 as percentage of tef grain flour $(0-40 \%)$ increased. However, the tef incorporation level was significant $(\mathrm{p}<0.05)$ at above $10 \%$ incorporation level. The decrease could be due to of the decrease in bread volume caused by the dilution of the gluten level increased fiber content in the corresponding dough that led to poor rising of the dough and lower gas retention capacity prior and during baking.

The overall acceptability score of the composite bread ranged from 2.95 to 4.84. Most composite bread samples showed a good degree of overall acceptance, it was observed that control sample $(100 \%$ refined wheat flour) was very well accepted because it exhibited the characteristics desired by the consumers. In contrast, maximum tef incorporated (40\% tef and 60\% refined wheat flour) was less accepted .

\section{Conclusion}

Loaf volume, color, texture and overall acceptability were deeming as common optimum parameter for bread formula. Tef grain flour can be used up to $15 \%$ in production of tef - wheat composite bread without significant effect on physical and sensory qualities acceptable by consumers. The formula containing $85.46 \%$ wheat farina flour and $14.56 \%$ tef flour was selected as the best formulation to produce a nutrient rich bread product with desirable texture and sensory quality.

\section{References}

AACC (2000). American Association of Cereal Chemists International (AACC, 2000 Method No 38-10). Approved Methods of Analysis, eleventh ed. AACC International, St Paul, MN, USA

AOAC (2010). American official methods of analysis, 20th edition. AOAC International Association of Official Analytical Chemists, Washington, DC, USA, Official Methods 925.09,923.03, 979.09, 962.09, 4.5.01.

Abebe W and Ronda F(2014). Rheological and textural properties of tef [Eragrostis tef (Zucc.) Trotter] grain flour gels. Journal of Cereal Science $60: 122-130$.

Alaunyte I, Stojceska V, Plunkett A, Ainsworth P and Derbyshire E(2012). Improving the quality of nutrient-rich Tef ( Eragrostis tef) breads by combination of enzymes in straight dough and sourdough bread making. Journal of Cereal Science 55:22-30. 
Baye K (2014). Tef: nutrient composition and health benefits. review. International Food Policy Research institute. ESSP, EDRI. Working paper 67.

Ben-Fayed EAP and Stojceska V (2008). The incorporation of tef ( Eragrostis tef) in bread-making. Technology Cereal Food World 53:A863.

Bultosa G. (2007). Physicochemical Characteristics of Grain and Flour in 13 Tef [Eragrostis tef (Zucc.)Trotter] Grain Varieties.Journal of Applied Science Research, 3, 2042-2051.

Bultosa G and Taylor J (2004). Tef. In: Wrigley C, Corke H and Walker C. (eds.). Encyclopedia of grain science 3: $281-290$, Elsevier Ltd. pp

CSA (2017) (Central Statistical Agency) (2016/2017). Agricultural sample survey report. Vol. I. report on area and production for major crops (private peasant holdings, meher season). Statistical Bulletin, Addis Ababa, Ethiopia, 2016

Coleman J, Abaye O, Barbeau W and Thomason W (2013).The suitability of teff flour in bread, layer cakes, cookies and biscuits. International Journal of Food Science and Nutrition 64(7): 877-881.

Gebremariam M, Zarnkow M and Becker T (2012). Tef (Eragrostis tef) as a raw material for malting, brewing and manufacturing of gluten-free foods and beverages: a review. Journal of Food Science and Technology.

Gómez M, Ronda F, Blanco C A, Caballero P A and Apesteguía A (2003).Effect of dietary fibre on dough rheology and bread quality. European Food Research and Technology 216: 51-56.

Hager A, Wolter A, Jacob F, Zannini E and Arendt K (2012a). Nutritional properties and ultra-structure of commercial gluten free flours from different botanical sources compared to wheat flours. Journal of Cereal Science 56: 239-247.

Hopman G, Dekking E, Blokland M, Wuisman M, Zuijderduin W, Koning F, Schweizer J, 2008. Tef in the diet of celiac patients in the Netherlands. Scandinavian Journal of Gastroenterology 43: 277-282.

Laike K, Solomon W, Geremew B and Senayit Y (2010). Effect of extrusion operating conditions on the physical and sensory properties of tef (Eragrostis tef [Zucc.]Trotter) flour extrudates. Ethiopian Journal of Applied Science Technology 1: 27-38.

Mepba H D, Eboh L and Nwaojigwa S U (2007). Chemical composition, functional and baking properties of wheat-plantain composite flours. African Journal of Food, Agriculture Nutrition and Development 7(1): 1 22

Mohammed M, Mustafa A and Osman G (2009). Evaluation of wheat breads supplemented with Teff (Eragrostistef(ZUCC.) Trotter) Grain flour. Australian Journal of Crop Science 3(4):207-212

Oyeyinka SA, Oyeyinka AT, Karim OR, Kayode RM, Balogun MA, Balogun OA (2013). Quality attributes of Weevils (Callosobruchus Maculatus) infested cowpea (Vigna Unguiculata) products. Journal of Agricultural Food and Environment 9 (3):16-22.

Stojceska V, Ainsworth P, Plunkett A and Ibanoglu S (2010). The advantage of using extrusion processing for increasing dietary fiber level in gluten-free products. Journal of Food Chemistry 121: 156-164. 